Title Page

\title{
Reformed Scholastic Philosophy in the Seventeenth-century Scottish
}

\section{Universities}

\author{
Giovanni Gellera
}

ORCID IDENTIFIER 0000-0002-8403-3170

Section de philosophie, Université de Lausanne

giovanni.gellera@unil.ch

Penultimate draft. The Version of Scholarly Record of this article is published in:

Scottish Philosophy in the Seventeenth Century, edited by Alexander Broadie. Oxford: Oxford University Press, 2020, pp. 94-110.

https://global.oup.com/academic/product/scottish-philosophy-in-the-seventeenth-century$9780198769842 ? \mathrm{cc}=\mathrm{gb} \&$ lang $=\mathrm{en} \&$

\begin{abstract}
In this chapter I formulate and analyse the definition of the philosophy of the seventeenthcentury Scottish universities in terms of 'Reformed scholasticism'. Scholastic philosophy was still central to university teaching after the Reformation, and the Scottish universities produced a great synthesis of Reformed theology and scholastic philosophy. My main focus is on metaphysics: I argue that the Reformed understanding of the Eucharist as a symbol motivated the choice for the views that accidents essentially inhere in their substances and that matter is essentially extended. These views are central to Reformed metaphysics, and qualify Scottish scholasticism as 'Reformed'. They are also coherent with the tradition of Scotism, to which the Scottish scholastics adhered: I argue that they represent developments of Scotism despite being against Duns Scotus's own views. The analysis provides evidence of an original and lively philosophical tradition, an innovative synthesis of Reformed instances, Scotism and Renaissance scholasticism. It was important on a national level, for it influenced philosophy for the whole seventeenth century, and on an international level, through the Scottish presence in the French Protestant academies. The formulation of Reformed scholasticism is a, so far unrecognised, great achievement of the Scottish universities.
\end{abstract}


Gellera, Reformed Scholastic Philosophy in the Seventeenth-Century Scottish Universities 


\section{Chapter Six}

Reformed Scholastic Philosophy in the Seventeenth-century Scottish Universities

\section{Giovanni Gellera}

\section{Introduction}

The Reformation is a watershed in Scottish history. It permeated most aspects of Scottish cultural life and repositioned Scotland geo-politically, ultimately paving the way for the twostage unification with England (1603 and 1707). The Scottish philosophers gradually diverted their gaze from France, which had been the principal reference and destination for Scots abroad since the time of Duns Scotus, to England and the United Provinces. Old and new commercial, social, and cultural ties replaced the role of Catholic France in Scottish life. 1

Whereas ample attention has been devoted to the study of the Reformation from the cultural, social, historical, and theological perspectives, this chapter investigates the Reformed scholastic philosophy of the seventeenth-century Scottish universities. The Scottish regents produced an original synthesis of scholastic philosophy and Reformed views. Scottish Reformed philosophy was also influential abroad because of the intellectual network of the Scots who worked in the Protestant Academies in France, until the Revocation of the Edict of Nantes (1685),2 and in the universities in the United Provinces. Hence, a 'philosophical' history of Reformation and post-Reformation Scotland can also be narrated.

The chapter is divided into six parts. Part one contextualizes Reformed philosophy in the curriculum of the Scottish universities. Parts two, three, and four treat diverse characteristic aspects of Scottish Reformed philosophy: the doctrine of the Fall, the Calvinist division of sciences, and the philosophy of the Eucharist. Part five looks at the legacy of Scotism and its relationship with the Scottish reception of Descartes (1650-1690). Lastly, part six outlines the European dimension of Scottish Reformed philosophy: its place within the European Reformation and the network of the Scots abroad in France and the United Provinces. 3

\footnotetext{
1 See Mijers 2012.

2 See Marie-Claude Tucker's chapter in this volume.

3 I do not treat moral and political philosophy. See Maurer's chapter in this volume, which contributes the moral philosophical side to the definition of Scottish Reformed scholasticism.
} 
1. Reformed scholastic philosophy and the universities

Scottish Reformed scholastic philosophy gradually developed in the universities after the Scots converted to the Reformed faith in 1560 . The practice of printing the graduation theses at the end of the four-year curriculum for the public graduation ceremony started only in 1596 in Edinburgh: the first example is the Theses philosophica by regent George Robertson for the University of Edinburgh.4 We can reconstruct the actual content of the philosophy of the regents before that date only indirectly. Steven J. Reid has investigated the Scottish curricula and the influence exerted by Andrew Melville as the principal actor of a Reformed as well as Humanist reformation of the universities. 5 The five Scottish universities entered the seventeenth century either as new foundations of medieval institutions (St Andrews 1413, Glasgow 1451, King's College 1495) or as new foundations entirely (Edinburgh 1583 and Marischal College 1593). Scotland could boast more universities than England or the United Provinces. Behind this high number of universities were the needs of an educated lay élite accustomed to the new Renaissance Humanist spirit, but also the imperative of the education of the clergy to the Reformed faith. The importance of the pedagogical, polemical, and apologetic role of the universities in the post-Reformation period cannot be overstated.

Whereas the university education was re-aligned from traditional Catholic scholasticism to the Reformation, many practical factors and considerations prevented a more clear-cut break with the past, hoped by many in the universities such as Andrew Melville. One such factor was the unavoidability of scholasticism. The regents of the Faculties of Arts went on teaching philosophy in the scholastic fashion on the Aristotelian corpus and literature, by way of quasstiones and lectiones. The repudiation of the Roman Church did not entail the repudiation of scholasticism as the best academic philosophy available. Some medieval authors, especially Thomas Aquinas and John Duns Scotus, maintained an authority untarnished by the contemporary confessional conflicts, in which the regents were otherwise happy to drag the Jesuits, especially Francisco Suárez and Robert Bellarmine.

The early Scottish scholastic philosophical sources belong to the period of the creation of a "Reformed Orthodoxy" (Muller, 1987). In Geneva, the United Provinces, and Scotland the first generations of Reformers typically reacted negatively to scholastic philosophy: among 
the thorny issues was the overlap of metaphysics and theology. Gradually, the needs of the ideological battle in the name of the European Reformation advised for moderation regarding scholasticism. Scholasticism could not be easily dismissed because it was omnipresent in the universities and it was the main battleground of the ideological battle against the Catholics. The Reformed scholars thus embraced the potentialities of scholasticism and produced a new Reformed scholastic literature which helped the Scottish regents build their own curriculum.6

During the Renaissance, Scottish philosophy was a lively tradition, and the use of philosophy for the purposes of theology was common. So Melville used Ramism to the advantage of radical Presbyterianism, 7 and before him in the circle of John Mair "the logic and philosophy developed by the medieval logicians were theologians' tools."8 The Scottish seventeenth-century lacks an Andrew Melville in philosophy. The creation of a more or less standard Reformed scholastic philosophy curriculum among the five universities was neither the work of a single man of genius or of great influence, or the imposition of political or religious authorities. It was rather the consequence of the everyday work of the late sixteenthcentury and early seventeenth-century regents who understood philosophy from a Reformed perspective and sought to harmonise the two. Only a few individuals stand out. The Aberdeen Doctors, especially regent John Forbes of Corse at King's College and regents James Sibbald and Robert Baron at Marischal College.9 James Fairley, William King, and James Reid were regents in Edinburgh until from early 1610s to mid-1620s: their theses are among the best of the century and evidence of a high-quality teaching in Edinburgh at that time. James Dalrymple, First Viscount Stair, was regent in Glasgow between 1643 and 1646 and among the first voices critical of traditional scholasticism.10 Dalrymple was neighbour and friend to James Dundas, First Lord Arniston, a judge and a Covenanter. Dundas received his Reformed scholastic education under regent James Guthrie, St Leonard's College, St Andrews, in 1635-1639. In the final months of his life Dundas wrote the incomplete manuscript entitled

6 Among the most used sources are the Reformed Humanist Julius Cesar Scaliger and the Reformed theologian Bartholomëus Keckermann.

7 Reid 2011: 59.

8 Broadie 2009: 87.

9 Robert Baron authored two of the most important Scottish Reformed scholastic works of the period: the Metaphysica generalis (London, 1657, posthumous) and the Philosophia theologia ancillans (Aberdeen, 1621). On Baron's Reformed views on faith and natural reason, see Broadie 2014.

10 In his Theses Logica, Metaphysica... (Glasgow, 1646) as well as in the Physiologia nova experimentalis (Leiden, 1686). 
Idea philosophice moralis (1679) in which he expounds moral philosophy from a Reformed scholastic perspective and criticises modern philosophy, especially René Descartes and Thomas Hobbes.11 After the recent discovery of the Idea manuscript, James Dundas can be acknowledged as one of the most outstanding non-university Scottish scholastic philosophers of the period. Reformed scholastic philosophy was not confined to the chilly classrooms of the universities.

In general, though, seventeenth-century Scottish philosophy is primarily a philosophy by and for the universities, and the characteristic seventeenth-century philosopher working outside the university, as Descartes, Hobbes, Spinoza, Bayle and Locke, had done, seems to have been uncommon in Scotland.12 The relatively minor regents thus acquire quite a representative status in the history of early modern Scottish philosophy.

\section{The Doctrine of the Fall and philosophy}

Calvin describes the pernicious effects of the Fall on humankind's self-knowledge and morality ("our miserable condition") in Book II, chapter I of the Institutiones Religionis Christiance.13 In the seventeenth century, Calvin's position was translated into an article of the Westminster Confession of Faith (1647): chapter 6.II, which reads that "By this sin they [Adam and Eve] fell from their original righteousness and communion with God, and so became dead in sin, and wholly defiled in all the parts and faculties of soul and body." Bartholomëus Keckermann (1572-1609), a Reformed theologian and philosopher praised by the Scottish regents, attempted a more philosophical explanation of the Doctrine of the Fall. Before Adam's sin:

"It was nothing else but that absolute and perfect estate before the fall, consisting in the perfection of the understanding and the will of man. ... The prime Image [of God] was both in his minde and in his body. In his body there was perfect health and safety. In his minde there was understanding without errour; will without staine of sinne."14

\footnotetext{
11 Broadie 2013 and Broadie's chapter in this volume. The manuscript of the Idea philosophice moralis is being critically edited and translated by Alexander Broadie and Giovanni Gellera for Edinburgh University Press. 12 "Few major seventeenth-century philosophers managed to exist comfortably within the environment of a university." Tuck 1998: 13.

13 Calvin 1960; reissued 2006: II, 1.

14 Keckermann 1622: 32-33.
} 
The Fall caused the corruption of intellect and will, the two fundamental faculties investigated in scholastic theories of mind: intellect is the faculty of knowledge, will is the faculty of decision-making and morality. It is evident that Calvin's view has a direct bearing on philosophical anthropology.

The Scottish regents integrate the Doctrine of the Fall into the philosophy teaching. Regent Robertson writes in his 1596 theses that:

Because of the lamentable Fall, not only the will is darkened throughout its acts, due to a paralysis through licentious affects, but also the mind due to Theban sphinxes and Cymmerian darkness. The grievous human condition is not only in need of the cure of practical training, but also of the eye-medicine and sun of the contemplative science. 15

He is echoed by regent King in 1612: "Detestable betrayal by man, so that our affections are damaged, our will corrupt and depraved: so our mind is confused by the densest gloom of ignorance. Philosophy is the medicine of this disease of the soul." 16 The regents typically treat the Fall in the opening paragraphs of the theses: the theoretical dimension of the Fall as a premise to philosophical investigations is clear.17 Two views are important here. Firstly, there is no "absolute" corruption: within its limits, a well-trained mind can be trusted in the acquisition of worldly truths.18 Philosophy can deliver knowledge within the limits proper to the human mind, which ought not to be surpassed. Secondly, there follows the awareness of the demarcation between philosophy and theology. Only theology deals with those things which are given to us by Revelation and surpass the human mind.

The anthropology of the Fall seems to establish a limit to the rationalistic pretensions of scholastic essentialism and, later, Cartesian foundationalism.19 + Throughout the seventeenth century, the regents believed in the corruption of the mind as an anthropological fact. Despite

15 Robertson 1596: Physical theses I: "Lapsu flebili, non modo paralysi dissoluti affectus, transuersum acta voluntas, sed \& Thebanis sphingibus, Cymmerijs tenebris obtenebrata mens. Lugubris conditio humana non modo disciplina practica medelam, sed \& scientia contemplativa collyrium \& solem requisiuit."

16 King 1612: Physical theses I: "Execrabili hominis Apostasia, sicuti vitiati sunt affectus, corrupta ac depravata voluntas: ita mens densissima ignorantiae caligine obnubilata est. Morborum animi, cujus medicina est Philosophia."

17 The Doctrine of the Fall is also central to moral philosophy: see Christian Maurer's chapter in this volume.

18 Goudriaan 2006: 43: "because in view of these natural matters the human mind is not altogether blind,

[Gijsbertus] Voetius is able to acknowledge human accomplishments as well as the possibility of a natural theology that has certainty."

19 See further discussions of the Fall in chapter on Logic in this volume. 
this, they attributed only a marginal, methodological role to scepticism. At the peak of Descartes' influence on the curriculum, for example, regent Cockburn structures the incipit of his 1675 theses on the Cartesian notions of methodological scepticism, clear and distinct perceptions as criterion for truth, and the Cogito.20

\section{The division of sciences and metaphysics}

Calvin believed in the intrinsic limits of the human mind. He also taught that humankind is saved sola fide and that sola Scriptura ought to guide the believers.21 With a similar intent, the Westminster Confession repeatedly plays down the importance of natural light and proclaims the self-sufficiency of the Scriptures.22 In Muller's words: "Luther, Calvin, and the other early Reformers had little interest in elaborating a positive relationship between faith and philosophy. This is, of course, not to say that there was total antipathy to philosophical learning." 23 For example, the famous passage of the Letter to the Romans I, 19-20 was understood as evidence of the sense of divinity in humankind but also as grounds of natural theology in the manifestation of the invisible through the visible things. Despite this, Scholastic philosophy was arguably less essential to Reformed thought than it was to Catholic thought.

These beliefs are principles for the regents: they have consequences for the scope and division of the philosophical sciences inherited from the Catholics. According to Gaukroger, "the key problem that underlies the textbook tradition is the relation between metaphysics and natural philosophy." 24 The Catholic scholastics were generally Thomist in the pursuit of a coherent worldview in which "metaphysics bridges the two, so that while natural philosophy can be pursued independently to some degree, ultimately it must be subordinated to theology via this metaphysical bridge." 25 Regarding the division of science in Calvinist authors, Lohr has written that they "tended to distinguish clearly between two sciences, a science of God (to the extent that he is accessible to human reason) and a science of being (understood as a

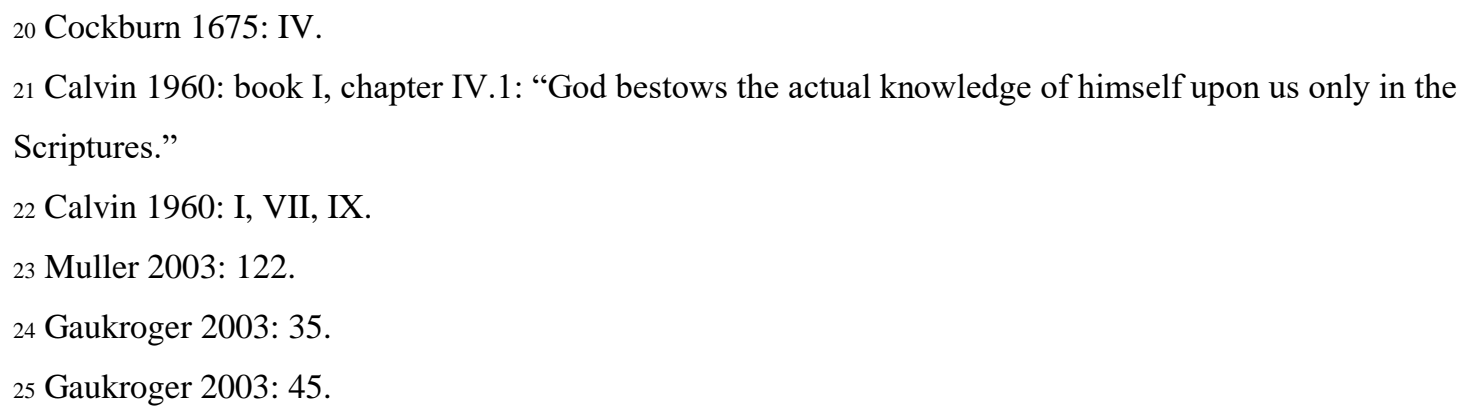


universal science which supplies the principles for all the particular sciences)." This led to "a system of precepts and rules, methodically ordered, through which one can - with the requisite natural ability and corresponding practice - gain the habit of knowledge in the liberal arts." 26 The best known version of the Calvinist division of science was introduced by Clemens Timpler in the Metaphysica systema methodicum (Hannover, 1606) and by Rudolph Goclenius in the Lexicon philosophicum (Frankfurt, 1613). There, in the entry 'Abstractio' the concept of ontology as Lohr's "universal science which supplies the principles for all the particular sciences" is first used. At the bottom lies the separation of metaphysics and natural theology.

The Scottish regents were less occupied with the relationship of theology and philosophy than were the Catholics. When Andrew Melville attempted to reform the universities "perhaps [he], who felt like many reformed theologians that metaphysics was overly speculative and unprofitable, was successful during his time as rector in removing it from the university curriculum.”27 Sections on metaphysics are often missing from the early seventeenth-century theses, though Melville's injunction did not prevent the regents from treating metaphysics in logic and natural philosophy. The Calvinist aspect of the division of sciences is precisely the absence of a metaphysical bridge between theology and philosophy. Alongside the traditional treatments of ens in quantum ens 28 and the transcendental unum, verum, bonum,29 metaphysics does not include God as its main object (God and creatures are treated as particular substances under their common formal concept of being) 30 and is not a natural theology. Theologians and philosophers consider the same truths about God (the Averroistic "double truth" is not an option) in different ways: faith versus demonstration.31

Traditionally, metaphysics deals with being abstracted from matter either by essence, as in God and the intelligences, or by indifference or non repugnantia, as in the transcendentals and categories.32 There is a tendency among the regents to understand abstraction in the strong sense of "exclusion of matter from the essence". So for example, regent William

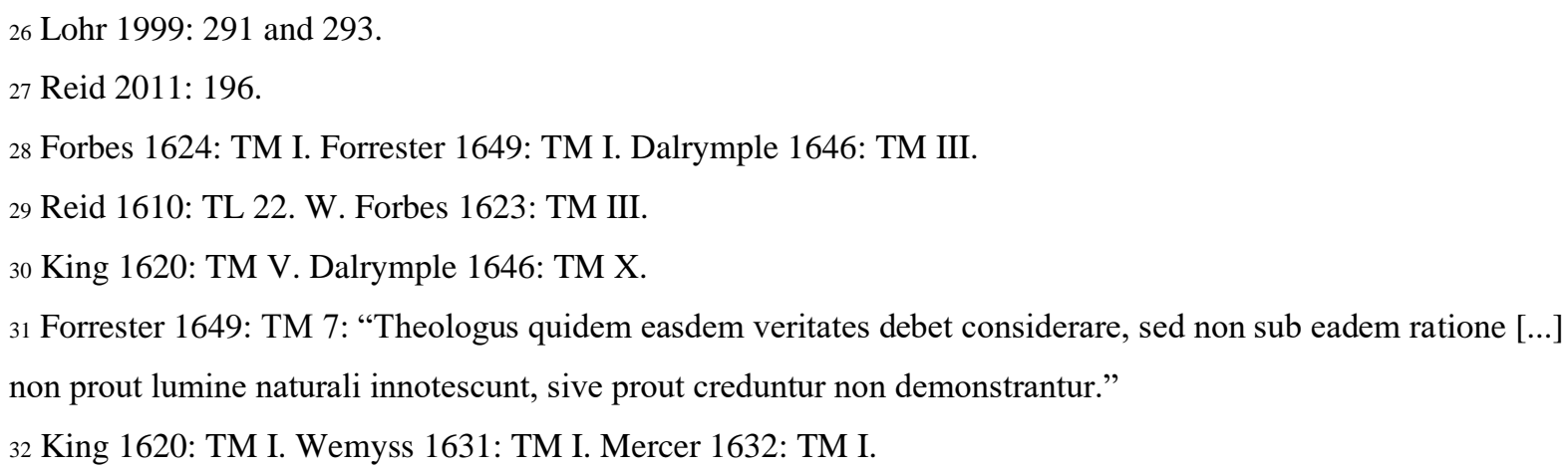


Forbes writes in 1623 that only the separate substances are known by the metaphysician;33 in 1613 regent Lamb claims that ens qua ratione ens is the object of metaphysics and qualifies it as "only those things which do not include matter in their concepts." 34 This suggests a separation of the sciences of metaphysics and physics based on the dualism of immaterial and material substances, as for example in Middleton (1675) and Grant 1(676):35 later in the century the regents will celebrate the separation of physics from sterile metaphysical speculation brought about by the new science. 36 Although these later views are heavily influenced by Descartes,37 it is suggestive to see a continuity with earlier Reformed scholasticism and the Calvinist system of science.

Borrowing Gaukroger's point about "the institutional attractiveness of Thomism" for the Catholic universities, 38 one can thus make a similar argument about the institutional attractiveness of the Reformed division of science for the Scottish Faculties of Arts. Throughout the seventeenth century, the goal of higher education was to educate the clergy and, in second order, the civil servants. In this sense, philosophy maintained a subordinate and propedeutic relation with theology, which the Arts regents were not allowed to teach. The Calvinist division of science was the result of the Reformed suspicion of philosophy and the related desire to keep theology and philosophy apart, of the belief in the intrinsic limits of natural reason, which tended to make theology-independent truth suspicious; but also of the need to have a lively academic philosophy, not least for apologetic purposes.

A perhaps unwanted consequence was the possibility (a danger from the theologian's perspective) of a philosophical enquiry ever more independent from theology. In the end, fewer obstacles were arguably there in Scotland than in the Catholic world for the establishment of empirical science in lieu of natural philosophy.

\section{The (meta)physics of the Eucharist}

33 Forbes 1623: TM II: “[naturas] eas tantum in suis conceptibus nullam materiam includunt, adeoque solas substantias separatas cognoscit Metaphysicus.”

34 Lamb 1613: TM I: "illæ tantum quæ in suis conceptibus nullam materiam includunt."

35 Middleton 1675: section VIII: “esse vel materialia seu corporea, vel immaterialia seu incorporea et spiritualia: priora sunt Physicae, posteriora Metpahysicae considerationis.” Grant 1676: sections V-X.

${ }_{36}$ Cockburn 1675: TPh XII. Skene 1696: TPh IX.

37 Gellera 2015 for the reception of Descartes in the seventeenth-century Scottish universities in metaphysics and natural philosophy.

${ }_{38}$ Gaukroger 2003: 42. 
One highly conflicting issue in the relations between theology and philosophy was the Eucharist. The Catholics were compelled to argue for the possibility of the miracle with the aid of philosophy; the Reformed aimed to keep philosophical speculations within their natural limits and preserve the self-sufficiency of the Scriptures. While avoiding theological disquisitions, the regents could nonetheless play an apologetic role by attacking the Catholics. This section and the next one on Scotism argue that the discussion of the Eucharist lies at the core of Scottish Reformed scholastic philosophy for the whole seventeenth century.

The seventeenth-century debates on the Eucharist have been given due scholarly attention. In the Scottish Reformed camp, less known than the theology of the Eucharist is the "philosophy of the Eucharist" of the regents of Arts.39 The Aristotelian metaphysics of substance and accident framed the discussion, further evidence of the enduring importance of the scholastic worldview. The Catholic position has the binding force of a dogma. During consecration, so goes the philosophical (that is, scholastic) explanation, the accidents of bread and wine are made to exist without their respective natural substances of bread and wine by divine power. The accidents are made to inhere in new substances, the body and blood of Christ. Hence, the body and blood of Christ look like bread and wine. The dogma is based on the literal reading of the Gospels of Matthew 26:26, Mark 14:22, and Luke 22:19: "Hoc est corpus meum".

The philosophical arguments devised by the Catholics hinge on the following points: a) because we know the substances only through the senses, and they report no changes during consecration, the accidents must persist without their substance; b) in order for the accidents to be separable from the substance, inherence in the substance (that is, the fact of being an accidental form of a substance) must be separable from the accident; c) something is separable from something else only if it is not essentially connected. Points (a) and (c) are accepted by all scholastics. Point (b) requires an argument, and a compromise with respect to Aristotelian orthodoxy.

Aristotle taught a deflationary or reductionist view of the accidents, for example in Metaphysics VII.1, on which the very distinction between accidents and substances hinges: substance is that which exists independently, accident is that which exists in something else,

39 I have argue that the Scottish regents and Franco Burgersdijk have an identifiable Calvinist position on the theory of accidents motivated by the Reformed rejection of transubstantiation. Here I rehearse some arguments and texts discussed in Gellera 2013. 
not as part of it. Hence, the Catholics devised the difference between 'aptitudinal' and 'actual' inherence: the former is attributed essentially, the latter is attributed only on the empirical evidence of whether a given accident inheres or not at any given moment.40 In the Eucharist, the accidents of bread and wine inhere in bread and wine only aptitudinally, hence they can be separated from their actual inherence by non-natural means, that is by God. According to Suárez, Aristotle thought the opposite deflationary view that by no means can the accidents ever be separated from their actual inherence.41 Suárez believes that this position is dangerous because if inherence is not separable from the accident then "one cannot understand how the accident is preserved without its actual inherence, although this is exactly what faith teaches us to be happening in the Eucharist." 42 The dogma of transubstantiation teaches against perceptual experience ("tamen") and the only evidence in support is given by the dogma itself: "from theological principles [...] chiefly because of the Eucharistic mystery." 43

John Calvin was not a sacramentarian, for him the presence of Christ in the host is more than a symbol. In Institutiones IV, 17, 19 "he professed 'we must establish such a presence of Christ in the Supper as may neither fasten him to the element of bread, nor enclose him in bread, nor circumscribe him in any way.' [...] He suggests that what the mind does not comprehend, then, let faith conceive." 44 In philosophy, what the Scottish regents could not comprehend was precisely how an accident could exist without its substance, as required by the Catholic transubstantiation. 45 This is not to say that the Reformed Eucharist has no unexplainable dimension to it: there is no rationalistic pretension to render the presence of Christ in the Supper a metaphysical question. Simply, the regents took the fact that the Catholic view is in contradiction with good Aristotelian philosophy as further evidence that the Catholic view is wrong.

\footnotetext{
40 Eustachius 1609: IV, Tractatus de principiis entis, II, VIII: “ Inhaerentiam quidem aptitudinalem in formali ratione accidentis contineri; verum inhaerentiam actualem saltem ex natura rei ab accidentis natura seu essentia esse diversam.”

41 Suárez 1597: 37, 2, 2.

42 Suárez 1597: 1, 16, 2: "intelligi non potest quomodo accidens sine sua actuali inhaerentia conservetur, quod tamen in Eucharistia fieri docet fides."

43 Suárez 1597: 40, 2, 8 : “ex principiis Theologiae [...] maxime propter mysterium Eucharistiae.”

44 Tylenda 1974: 72-73.

45 Same point in Descartes: "la transsubstantiation, qui les calvinistes reprennent comme impossible à expliquer par la philosophie ordinaire.” Descartes to Vatier, 22 February 1638, AT I: 564.
} 
A related difficulty for the regents came from Calvin's disengagement from scholastic terminology. When speaking of the "true and real presence" in the Supper, Calvin did not have in mind the Catholic presence "realiter et substantialiter" because the presence is intended as spiritual not physical.46 Yet, to regents trained in philosophical scholasticism the adjective realis was a reminder of the semantic field of realitas: something 'real' is something with a form, hence some actuality, a presence. 'Real' means true, and opposed to imaginary, mental, and verbal. 47 The transposition of Calvin's view of the presence of Christ in the Supper from a non-scholastic theology to philosophy inevitably raised questions which the regents sought to answered in scholastic philosophical terms.

The regents unanimously defend a reductionist view of the accidents in which actual inherence is essential to them. Regent Craig writes in 1599 that accidents "flow from the nature of the subject and are really inseparable from it." 48 Regent John Baron writes in 1627 that:

"It is no less impossible that an accident exists without its subject of inhesion, than a substance does not subsist, and inheres in something else. The accident's aptitudinal inherence cannot be separated from its actual inherence not even by God's absolute power; because this sort of separation implies a contradiction." 49

Concerning the exegesis of Aristotle, regent Robert Forbes in 1684 makes the same connection between Aristotle and the reductionist view of accidents but, unlike Suárez, he approves of it:

"The Doctors of the Pope come up with the real accidents, which can exist without a subject by divine decree, in their defence of Transubstantiation in the Eucharist. Neither Aristotle nor any of his followers admit accidents of this real sort." 50 According to the regents there is no exception to the Aristotelian view that the accidents naturally inhere in their substance: no miracle occurs which requires a philosophical 46 Tylenda 1974: 70.

47 Goclenius 1613: entry 'Realitas'.

${ }_{48}$ Craig 1599: logical theses 21.I: "promanant a natura subiecti, eoque a subiecto penitus inseparabilia." 49 Baron 1627: logical theses XI: "Non minus impossibile est accidens existere extra omne subjectum inhaesionis, quam substantiam non subsistere, sed alteri inhaerere. Aptitudinalis inhaerentia accidentis, non vel per ipsam Dei potentiam absolutam separari potest ab ejus inhaerentia actuali; quoniam hujusmodi separatio implicat contradictionem."

50 Forbes 1684: XIX: “Accidentia realia, quae divinitus existere possunt sine omni subjecto, comminiscuntur Doctores Pontificii, ad defendendam doctrinam suam de Transubstantiatione in Eucharistia: At nullum tale accidens reale admittit Aristoteles, cum ullus ex ejus germanis discipulis." 
explanation and which entails the revision of natural philosophy. Without overlooking the complex and nuanced tensions between theology and philosophy in the seventeenth century, at least on the issue of the theory of substance and accidents the regents saw no apparent conflict between Reformed faith and Aristotelian philosophy. The division of sciences seems to go in the same direction of the independence of theology and philosophy based on clear demarcations between the two. It is plausible that the Scottish regents' later positive reception of Descartes and of the English experimentalists was facilitated by this Reformed mentalité.

The metaphysics of the Eucharist taught by the regents had many advantages: it was deemed coherent with Aristotle and, later, Descartes; it had Reformed credentials without trespassing into theology proper; it served well the anti-Catholic polemics. It can be helpfully used as a marker of Scottish Reformed scholastic philosophy. The discussion of Scotism and its relationship with post-scholastic Scottish Cartesianism further highlights this interpretation.

\section{Scotism and post-scholastic philosophy}

Scotism in early modern philosophy has been the subject of recent interest.51 The new scholarly consensus is that Scotism was very influential in the late Renaissance and early modernity, doing justice to Johannes Caramuel y Lobkowitz's famous claim that the seventeenth-century school of Scotus is more numerous than all the other schools taken together. Scotism in the graduation theses of the early seventeenth century is investigated in another chapter of this volume where Jean-Pascal Anfray concludes that although there is no "Scottish specificity with regard to Scotism [...] Scotus contributed to a large extent to shape the philosophical debates within the Scottish universities."52. Here I limit myself to introducing Scotism when it is relevant to Reformed scholastic philosophy and Scottish Cartesianism.

On the relations between scholasticism and Descartes, Roger Ariew argued that "Descartes leans toward Scotism for every one of the Scotist theses, as long as they are relevant to his philosophy." 53 In the French academic context, Jean-Paul Pittion has spoken of

51 Broadie 1995 main argument is that Scotism is a fundamental tradition in Scotland until the Enlightenment. 52 Anfray 2016: 120.

53 Ariew 1999: 55. 
the French Protestants as "poussés vers le cartésianisme." 54 I have sought elsewhere to spell out the same connection between Scottish Reformed scholastic philosophy, on the one side, and Scotism and Cartesianism on the other, in the analysis of the late seventeenth-century reception of Descartes in the Scottish universities.55 The main conclusion is that the regents show a tendency to frame their metaphysics in Scotistic terms. Examples are the metaphysics of essence, the formal distinction between essence and existence, the attribution of an entitative act to prime matter.56 Although this tendency does not amount to a Scotistic "school", the interpretative hypothesis is that the Scotistic views prompted the favorable reception of similar Cartesian views from the 1670s onwards. Hence, Descartes' res extensa can be regarded in the light of the Scotistic doctrine that matter is endowed with an act on its own and that it exists without form. The reductionist theory of accidents motivated by the Reformed understanding of the Eucharist (which implies that the accident of extension is not really separable from matter, not even my divine power) can be related to Descartes's own deflationary view of modes. Whereas Suárez taught that "We approve of the argument which distinguishes in reality between quantity and substance",57 regent John Forbes speaks up for the Scottish Reformed view by criticizing the Catholics, "who teach that the accidents can exist outside a subject, and that the extended body is not measured by place. The former goes against the nature of accidents, the latter against the condition of the quantified body." 58 On matter and extension, regent King taught that "greater is the union of this quantity and matter, than of matter and substantial form." 59

Tantalising evidence of the affinity of Scottish Reformed philosophy and Descartes, as well as of the enduring importance of the Eucharist, is found in an argument by regent John

\footnotetext{
54 Pittion 1996: 442.

55 Gellera 2015: 183-184.

56 For example: Monroe 1632: Metaphysical section I.6: "Ergo essentia et existentia creaturae non differunt re sed ratione tantum.” King 1612: Physical section 2.IV: “Actus igitur materiae primae non et formalis et perfectus (habet enim a forma quod sit hoc aliquid formaliter) sed objectivus seu entitativus, per quem est id quod est extra nihil et suas causas." Forbes 1623: Physical section II: "Materia prima essentialiter est substantia incompleta, et pura potentia subjectiva (cui tamen actus entitativus competit).”

57 Suárez 1597: 40, 2, 8: “Approbatur sententia reipsa distinguens quantitatem a substantia”.

58 Forbes 1624: LT XVII: “docentes accidentia esse posse quamvis subjecto non insint, et corpus extensum, loco non mensurari. Quorum alterum accidentium naturæ, alterum corporis quanti conditioni ita adversatur."

59 King 1612: PT 3.V: "major igitur est unio inter quantitatem hanc et materiam, quam inter materiam et formam substantialem."
} 
Buchan in 1681 . The regent makes a point at once exegetical and theoretical concerning Descartes' philosophy:

"Indeed, the Cartesian hypothesis subverts the pontifical dogma of transubstantiation, for if the species (which the papists turn into accidents) remained after the destruction of the substance of bread and wine, they would be substances, that is they would exist on their own. And it is inconsistent with the nature of modes (and all accidents are modes) that they are, or are conceived without their subject, or that they move from subject to subject. What philosophizes our noble Philosopher about the surface, in the attempt to explain away the fact that the species are still there, no one can really understand: according to the author himself, the surface is, in fact, a mode. [...] The monstrous dogma of transubstantiation uproots the very foundations of good philosophy [...] It seems that our great Philosopher did not philosophize freely here, and was scared of the blows of the Popes." 60

Buchan attacks Descartes on the supposed incoherence between, on the one side, the argument that the external surface of the material substances can be separated by it because it is a mode and, on the other side, Descartes' overall reductionist account of accidents and modes.61 The reductionist metaphysics motivated by the Reformed scholastic philosophy of the Eucharist is thus central to Scottish philosophy teaching before and after the reception of Cartesianism. The fact that Descartes taught similar reductionist views of accidents was approved by the regents, and caused resentment when they perceived that Descartes had betrayed his own philosophy for fear of Catholic censorship.

There is evidence of a profound continuity between Reformed scholastic philosophy and later Scottish Cartesianism on some central views. In many cases Scotism constitutes the philosophical bridge. The delineation of Scottish Reformed philosophy and of its continuities before and after Descartes raises important questions on the philosophy of the Scottish

60 Buchan 1681: XLI: "Immo hypothesis Cartesiana subvertit pontificium transubstantiationis dogma, si enim species (quas accidentia faciunt pontificii) remaneant destructis panis et vini substantiis, substantiæ erunt, per se sciz. subsistentes. Inconsistens enim est cum modorum natura (omne autem accidens modus est) ut vel sint, vel concipiantur absque suo subjecto, vel transeaant de subjecto in subjectum. Quod autem Philosophatur nobilis Philosophus, de sua superficie, per quam aggreditur remanentes species explicare, videtur a nemine intelligi posse, superficies enim ea, secundum authorem, modus est [...] Monstrosum transubstantiationis dogma sane Philosophiæ fundamenta convellit [...] Videtur magnus Philosophus hic non libere philosophari, pontificium potius vereri fulmen.”

61 AT VII: 248-56. 
professors abroad and on the broader European dimension of Scottish Reformed scholasticism.

\section{The European dimension of Scottish Reformed scholasticism}

The Scots had strong connections with European universities and academies throughout the modern period. France, especially the Sorbonne in Paris, was a chosen destination and the Scots contributed to its philosophical fortunes during the Renaissance.62 The presence of Scottish academics in France did not stop when Reformed Scotland moved away from the auld alliance with France and looked to England. Prominent in early modern French cultural life were the Protestant academies, active variably between the Edict of Nantes 1598 and its revocation by Louis XIV in 1685 in towns like Saumur, Sedan, Montauban, Die.63 Some Scots became important professors in theology and philosophy. The theologian John Cameron taught in Sedan, Saumur, and Montauban, and was a public figure in the French Protestant camp.

Many Calvinists travelled from other countries to study and teach Reformed scholastic philosophy in Saumur. The Scot Marc Duncan was professor of philosophy in Saumur. His main work is in logic, the Institutionis logica libri quinque (Saumur, 1612), reprinted several times. Still extant are the graduation theses he wrote for the 1610 class in Saumur: Theses ex Logicis et Ethicis Selectæ.64 I have analysed Duncan's theory of accidents in relation to the Reformed Eucharist elsewhere.65 Another was the Dutch Reformed Aristotelian Franco Burgersdijk. He taught in Saumur between 1616 and 1619 where he was a colleague of Duncan and of Jacob Schewer (1617-18) previously regent at St Salvator's College, St Andrews.66 Burgersdijk later became an influential professor of philosophy at the University of Leiden until his death in 1635.67 He was also the teacher of the Cartesian Adriaan Heereboord, and René Descartes enrolled at the University of Leiden when Burgersdijk was

62 Broadie 2009: chapter 4 on the circle of John Mair.

63 See Marie-Claude Tucker's chapter in this volume on Scottish professors and students in the French Protestant academies, and Pittion 1996 on the philosophy of the academies. 64 I thank Jean-Paul Pittion for providing me with a copy of Duncan's theses. 65 Duncan 1612: 63: “Accidens enim separabile ipso separationis momento perit, et desinit existere in rerum natura." Gellera 2013: 1099-1100.

66 Where he authored the Theses Logica, Ethica, Physica (Edinburgh, 1614).

67 Verbeek 1992: 37. 
professor there. I have argued that Burgersdijk's reductionist metaphysics of accidents is motivated by his Reformed faith.68 It is probable that he discussed it with Marc Duncan considering his praises for him.69 Duncan and Burgersdijk defend similar reductionist views of accidents to those of the regents in the Scottish universities, so evidence points in the direction of a 'Reformed' consensus among the Scots home and abroad.

Some notable Scottish Reformed philosophers taught in the United Provinces. Gilbert Jack was professor in Leiden for twenty-five years. Steuart was professor in Saumur (1617), then in Leiden (1644). He took side in the so-called "Leiden crisis" concerning the philosophy of Descartes, in particular against Adriaan Heereboord.70 A network emerges of several personal and philosophical connections between the Scottish Reformed philosophers who worked in the French academies and in the Dutch universities, especially Leiden. The network of the Scottish diaspora and its specific philosophical contributions call for further investigation.

Another underexplored topic is the intellectual map of early modern Reformed scholastic philosophy. Important distinctions between the strands of Reformed scholastic philosophy seem to emerge: one strand is what one might call the 'Scottish tradition', and the other the German Schulmetaphysik. The main philosophers of the Schulmetaphysik were all of German extraction: Clemens Timpler, Rodolphus Goclenius, and Johannes Clauberg. Their greatest achievement is the reformulation of Catholic metaphysics, especially Benedictus Pereira's $D e$ communibus omnium rerum naturalium principiis (Rome: 1576) and Francisco Suárez, in terms of ontology: that is, the science of being qua being, more general and prior to the Aristotelian concept of the metaphysics of substance. There is no similar development in Scottish regents' metaphysics. Johannes Clauberg sits at the crossroads between the Schulmetaphysik and the reception of Descartes in Germany in the same way as the Scottish regents do in Scotland.71

Reformed scholastic philosophy seems to have developed at least two different strands in Scotland and France, and in Germany respectively, with the United Provinces somehow divided between French and German cultural influences. More research is needed on the specific contributions of these two traditions to early modern philosophy, especially Cartesianism.

${ }_{68}$ Gellera 2013: 1100-1101. Van Ruler has argued that Burgersdijk's metaphysics shows no signs of specific Reformed views and his rather reliant on Suárez's Disputationes metaphysica, see van Ruler 1993. 69 Hutton 2015: 79.

70 Verbeek 1992: 34 and following. On Jack and Steuart respectively, Hutton 2015: 54-55, 78-79.

71 See Vincent Carraud's chapter on Schulmetaphysik and Cartesianism in Clauberg in Verbeek 1999. 


\section{Conclusion}

The Scottish regents created an original synthesis of Reformed faith and scholastic philosophy. Three main Reformed views became principles of the Arts Reformed philosophy curriculum: 1) the Doctrine of the Fall, which suggests the intrinsic limits and fallibility of the human mind; 2) the sola fide principle, which is reflected in the conscious separation of theology and philosophy. Metaphysics is not the connecting science between philosophy and theology; 3) the Eucharist: the non-substantial presence of Christ translates into a reductionist account of accidents and matter, which the regents consider as "good Aristotelian philosophy". The defining and unifying role played by the Reformed faith in the regents' philosophy is twofold: positively, in the adherence to these views as a collective marker of Reformed philosophy and, negatively, in the opposition to Catholic philosophy.

The qualifications 'scholastic' and 'Scottish' are equally important. Scottish Reformed scholastic philosophy belongs to the scholastic tradition, visible in the Aristotelian categories of thought, the literature, the teaching style, and the methodologies employed. 'Scholasticism' in this sense is a way of doing philosophy, rather than an identifiable philosophical content. The 'Scottish' dimension of Scottish Reformed scholastic philosophy lies in the fact that it exerted influence also beyond Scotland thanks to the Scottish professors in France and in the United Provinces, and that it differed from the coeval Calvinist German Schulmetaphysik, where ontology develops and substance dualism and reductionist metaphysics are less prominent.

On a longer temporal scale, the relevance of Reformed philosophy in Scottish culture did not end with the seventeenth century and, besides Cartesianism, Newtonianism, and experimental philosophy, it remained central in the definition of the intellectual landscape of the first generation of the Enlightenment, when the young Francis Hutcheson, David Hume, and Thomas Reid received their university education. The appreciation of the distances they travelled also lies on the better understanding of their point of departure.

Bibliography

Adam, C. \& Tannery, P. (eds). (1974-86). Oeuvres de Descartes. Paris: C.N.R.S.-Vrin. Anfray, J.-P. (2016). Scottish Scotism? The Philosophical Theses in the Scottish Universities, 1610-1630. History of Universities, XXIX/2: 96-120. 
Ariew, R. (1999). Descartes and the Last Scholastics. Ithaca-London: Cornell University Press.

Baron, J. (1627). Theses aliquot philosophicae. Edinburgh: St Salvator's College, St Andrews.

Baron, R. (1657). Metaphysica generalis. London: J. Redmayne.

Baron, R. (1621). Philosophia theologia ancillans. Aberdeen: E. Raban.

Broadie, A. \& Reid S. J. (eds.). (forthcoming 2019). Philosophical Discourse in SeventeenthCentury Scotland: Key Texts. Edinburgh: Scottish History Society.

Broadie, A. (2013). James Dundas on the Hobbesian State of Nature. Journal of Scottish Philosophy, 11 (1): 1-13.

Broadie, A. (2014). Robert Baron on the Assent of Faith. Journal of Scottish Philosophy, 12 (2): $231-242$.

Broadie, A. (2009). A History of Scottish Philosophy. Edinburgh: Edinburgh University Press.

Broadie, A. (1995). The Shadow of Scotus. Edinburgh: T. \& T. Clark.

Buchan, J. (1681). Theses philosophica. Aberdeen: King's College.

Calvin, J. (1960). Institutes of the Christian Religion, ed. J. T. McNeill. Louisville: The Westminster Press. 1960; reissued Louisville: Westminster John Knox Press, 2006.

Cockburn, A. (1675). Theses philosophicae. Edinburgh: St Leonard's College, St Andrews.

Craig, W. (1599). Theses philosophicae. Edinburgh: University of Edinburgh.

Dalrymple, J. (1646). Theses Logica, Metaphysica. Glasgow: University of Glasgow.

Dalrymple, J. (1686). Physiologia nova experimentalis. Leiden: C. Boutesteyn.

Duncan, M. (1612). Institutionis logica libri quinque. Saumur: D. Lerpinfrium.

Duncan, M. (1610). Theses ex Logicis et Ethicis Selectce. Saumur: T. Portaeus.

Dundas, J. (1679). Idea philosophice moralis. Unpublished MS.

Eustachius (1609). Summa philosophia quadripartita. Paris: C. Chastelain.

Forbes, R. (1684). Theses philosophica. Aberdeen: King's College.

Forbes, J. (1624). Theses philosophicae. Aberdeen: King's College.

Forbes, W. (1623). Positiones aliquot logicae, ethicae, physicae, metaphysicae, sphericae.

Aberdeen: King's College.

Forrester, D. (1649). Theses philosophicas. Edinburgh: University of Edinburgh.

Gaukroger, S. (2003). Descartes' System of Natural Philosophy. Cambridge: Cambridge University Press. 
Gellera, G. (2013). Calvinist Metaphysics and the Eucharist in the Early Seventeenth Century. British Journal for the History of Philosophy, 21 (6): 1091-1110.

Gellera, G. (2015). The reception of Descartes in the seventeenth-century Scottish universities: metaphysics and natural philosophy (1650-1680). Journal of Scottish Philosophy, 13 (3): 179-201.

Goclenius, R. (1613). Lexicon philosophicum. Frankfurt: M. Becker.

Goudriaan, A. (2006). Reformed Orthodoxy and Philosophy, 1625-1750. Leiden: Brill.

Grant, A. (1676). Theses hasce ac observationes Philosophicas. Edinburgh: St Leonard's College.

Hutton, S. (2015). British Philosophy in the Seventeenth Century. Oxford: Oxford University Press.

Keckermann, B. (1622). A Manuduction to Theologiae, or Heavenly knowledge directing a Christian to ye assurance of his salvation in this life, trans. T. V. London: Aug. Mathewes. King, W. (1612). Theses philosophica. Edinburgh: University of Edinburgh. King, W. (1620). Theses philosophicae. Edinburgh: University of Edinburgh. Lamb, W. (1613). Positiones aliquot logicae, ethicae, physicae, metaphysicae, astronomicae \& cosmographicae. Edinburgh: St Salvator's College.

Lohr, C. H. (1999). Metaphysics and natural philosophy as sciences: the Catholic and Protestant views in the sixteenth and seventeenth centuries. In Blackwell, C. \& Kusukawa, S. (eds.), Philosophy in the Sixteenth and Seventeenth Centuries. Conversations with Aristotle (280-295). Aldershot: Variorum.

Maurer, C. (2016). 'A Lapsu Corruptus': Calvinist Doctrines and Seventeenth-Century Scottish Theses Ethicae. History of Universities, XXIX/2: 188-209.

Mercer, J. (1632). Theses aliquot logicae, ethicae, physicae, metaphysicae, atronomicae, geometricae. Edinburgh: St Leonard's College.

Middleton, G. (1675). Theses philosophicae. Aberdeen: King's College.

Mijers, E. (2012). "News from the Republick of Letters": Scottish students, Charles Mackie, and the United Provinces, 1650-1750. Leiden: Brill.

Monroe, A. (1632). Theses aliquot philosophicae. Edinburgh: St Salvator's College.

Muller, R. A. (2003). After Calvin. Oxford: Oxford University Press.

Muller, R. A. (1987). Post-Reformation Reformed Dogmatics: The Rise and Development of Reformed Orthodoxy, ca. 1520 to ca. 1725. Grand Rapids, MI: Baker Academic. Pereira, B. (1576). De communibus omnium rerum naturalium principiis. Rome. 
Pittion, J.-P. (1996). Notre maître à tous: Aristote et la pensée réformée française au XVIIe siècle. In Magdelaine M. \& al. (eds.), De l'humanisme aux Lumières. Bayle et le protestantisme (429-443). Oxford: Voltaire Foundation.

Reid, J. (1610). Theses philosophicae. Edinburgh: University of Edinburgh.

Reid, S. J. (2011). Humanism and Calvinism: Andrew Melville and the Universities of Scotland 1560-1625. Farnham, Surrey - Burlington, VT: Ashgate.

Robertson, G. (1596). Theses philosophica. Edinburgh: University of Edinburgh

Schewer, J. (1614). Theses Logica, Ethica, Physica. Edinburgh: University of Edinburgh.

Skene, G. (1696). Decermina haec Philosophica. Aberdeen: King’s College.

Suárez, F. (1597). Disputationes metaphysica. Cologne.

Timpler, C. (1606). Metaphysica systema methodicum. Hannover.

Tuck, R. (1998). The Institutional Setting. In Garber, D. \& Ayers, M. (eds.), The Cambridge History of Seventeenth-Century Philosophy (9-32). Cambridge: Cambridge University Press. Tylenda, J. N. (1974). Calvin and Christ's Presence in the Supper - True or Real. Scottish Journal of Theology, 27 (1): 65-75.

van Ruler, J. A. (1993). Franco Petri Burgersdijk and the Case of Calvinism Within the NeoScholastic Tradition. In Bos, E. P. \& Krop, H. A. (eds.), Franco Burgersdijk (1590-1635): Neo-Aristotelianism in Leiden (36-55). Amsterdam: Rodopi.

Verbeek, T. (1992). Descartes and the Dutch. Carbondale: Southern Illinois University Press. Verbeek, T. (ed.). (1999). Johannes Clauberg (1622-1665) and Cartesian Philosophy in the Seventeenth Century. Dordrecht: Springer.

Wemyss, G. (1631). Theses aliquot philosophicae. Edinburgh: St Leonard's College. 